\title{
Extra-financial Analysis of IFRS Adoption and Application in Developing Country: The Case of Indonesia
}

\author{
Bienmali Kombate, Bandi \\ Sebelas Maret University of Surakarta, Surakarta, Indonesia
}

\begin{abstract}
This study was aimed to investigate the challenges and impacts of International Financial Reporting Standards (IFRS) adoption and implementation in Indonesia, an emerging country by focusing on extra-financial factors analysis. A series of questionnaires was built up regarding some selected items which have a marginal effect on IFRS adoption and implementation by Indonesian companies, the first part of the questionnaires was designed to gather information relating participants background, the second part of the questionnaire was set to collect participants opinion regarding IFRS adoption and implementation in Indonesia, and the third part of the questionnaire was an open questionnaire to enable the participants to give them suggestion or any additional information they feel can help IFRS adoption and implementation in Indonesia. The findings of this investigation reveal that Indonesia companies have facing several challenges and impacts in their IFRS adoption and implementation such as legal system, taxation system, economy and political ties, accounting education and its infrastructure, and culture structure. To ensure adoption and effective implementation of IFRS, Institute of Indonesia chartered accountants (IAI), Indonesia government, Indonesia accounting body and academic must work together to reform the consistence of accounting standard for better applicability of IFRS in ensuring transparent information environment.
\end{abstract}

Keywords: IFRS, IAI, developing country, Indonesia

\section{Introduction and Background}

According to Hans Hoogervorst, chairman of the International Accounting Standards Board (IASB) in his speech at the International seminar on "IFRS Dynamics 2013 and Beyond: Impact to Indonesia" organized by the Indonesian Institute of Accountants (Ikatan Akuntan Indonesia, IAI), encouraged all companies in Indonesia to follow a gradual convergence process to fully embrace of IFRSs. In this mission, the standard-setting body in Indonesia is the Financial Accounting Standards Board (Dewan Standar Akuntansi Keuangan or DSAK) under the Indonesian Institute of Accountants (Ikatan Akuntan Indonesia or IAI). Under Indonesian law, it was announced that all companies either public or private must comply with accounting standards, issued by the DSAK-IAI. However with this gradual converge of IFRS which was announced early 2012 by Indonesian government, both Indonesian companies public and private are facing some difficulties in IFRS implementation in their annual financial reporting. Nevertheless, the lack of research and limited research has been undertaken in understanding the pathway of the transition towards the use of the financial common language IAS/IFRS in this country.

Bienmali Kombate, lecturer of accounting and finance at the University of Lome (UL), Togo.

Bandi, M.Si., Ak, Dr., associate professor, accounting and finance lecturer at Universitas Sebelas Maret (UNS).

Correspondence concerning this article should be addressed to Bienmali Kombate, lecturer of accounting and finance at the University of Lome (UL), Togo, Boulevard Eyadema. 
Despite all the progress and obstacles in IAS/IFRS implementation in Indonesia in recent years, and limited studies focused on the gradual convergence of Indonesian accounting standards during the IFRS transition period, some previous study such as Perera and Baydoun (2007) examined the accounting ecology in Indonesia, and highlighted the prospects for the adoption of IFRS in the country. Whilst Perera and Baydoun's study is important in providing a description of the Indonesian accounting environment and the structural issues that may prevent the country from adopting IFRS, which only focuses on the particular period leading up to the IFRS convergence programs; Agus and Parmod (2014) study the progress of Indonesian IFRS implementation; Enggar Diah (2013) develops his research on IFRS and the quality of financial statements in Indonesia. The present study will seek the challenges and obstacles that Indonesian companies face in IFRS application by focusing on extra-financial factors analysis.

\section{Literature Review of IAS/IFRS in Emerging Countries}

Several researchers (Zeghal \& Mhedhbi, 2006; Hassan, 2009; Gyasi, 2010; Mohamed, 2014) all argued that international accounting harmonization is beneficial for developing countries because it provides them with better-prepared standards as well as the best quality accounting framework and principles. However, others such as Cerne (2009) mentioned that the accounting information produced according to developed countries' accounting systems is not relevant to the decision models of emerging economics. The ultimate decision to adopt IFRS or not, however largely depends on certain motivating or discouraging factors which exist in a particular country or group of countries.

Some emerging economies have taken the initiative to adopt IFRS such as Jordan, China, Poland, and the United Arab Emirates (UAE) or adapt them to their particular reality as observed in Egypt. This process is expected to improve the quality and credibility of financial reporting and develop the flow of capital and investment, resulting in economic development. While most of Middle Eastern Countries require or allow companies under their financial authorities to use the globally known IFRS, only Indonesia, Syria, Morocco, Libya, and Algeria have developed their national Generally Accepted Accounting Principles (GAAP) and are still asking companies under their financial authorities to follow them, and are not allowing any company to use other standards (Abd El-Razik, 2009). However, IFRS are also permitted (Abd El-Razik, 2009). The adoption of IFRS by the developing countries is not only imperative (Faraj \& Akbar, 2010), but also required in order to access the capital markets at the global level. It is an international trend, which is recognized as best practice around the world (Obaidat, 2007).

The adoption of IFRS had become a significant global phenomenon (Al-Hussaini, 2008). Richter Quinn (2004) concluded that accounting and financial information originating from developing countries is still difficult to trust, despite the urgent need for these countries to attract foreign investment and foreign capital, and despite the pressing demands from individual and institutional investors, lending institutions, and multinational agencies. Irvine and Lucas (2006) state that substantial benefits have been proposed by the adoption of IFRS, including a decreased cost of capital, greater mobility of capital, greater efficiency in the allocation of resources, improved and more comparable financial reporting, and a decrease in the opportunities for earnings management expression. These, together with the accountability demands of the World Bank (WB) and the International Monetary Fund (IMF), make a compelling case for the adoption of IFRS by developing countries as they seek to participate in the wealth and financial opportunities promised by globalization.

Emerging economies, in pursuing the global financial advantages offered by the adoption of that common financial language, IAS/IFRS, are facing some obstacles and challenges due to the nonfinancial factor linked to 
the social, economic, and political environment. For instance, few studies are aimed on these factors to seek the problems facing emerging countries in their IFRS application.

Mohamed (2014), Irvine and Lucas (2006), Zhang (2007), and Michas (2010) highlight that, in emerging market countries, there are often deficiencies in the accounting and auditing practices. Furthermore, Alp and Ustuntage (2009) and Zhang (2007) all reported that, implementing IFRS by developing countries posed several challenges. Such difficulties include the complex structure of the international standards, potential knowledge shortfall and other difficulties in the application and enforcement issues. While embracing globalization, and adopting IFRS, it nevertheless has challenges ahead as it makes necessary reforms to its regulatory, legal, and economic structures and adapts its culture to westernized forms of expression (Irvine \& Lucas, 2006). Emerging economies face challenges if they want to implement IFRS.

Table 1

Summary of Some Key Previous Studies

\begin{tabular}{|c|c|c|c|}
\hline Author(s) & Country's study & Main objective(s) & Main finding(s) \\
\hline $\begin{array}{l}\text { E. Boumediene } \\
\text { and } \\
\text { S. Boumediene } \\
(2013)\end{array}$ & France & $\begin{array}{l}\text { To show that in accordance with the } \\
\text { expectations of international } \\
\text { organizations, the adoption of IFRS } \\
\text { increases the information content of } \\
\text { financial statement and also to identify } \\
\text { the key accounting variables that have } \\
\text { been affected by this adoption }\end{array}$ & $\begin{array}{l}\text { The findings of this paper show that the application of } \\
\text { IFRS as accounting standards increases the } \\
\text { accounting information. }\end{array}$ \\
\hline Nnadi (2012) & $\begin{array}{l}\text { Ghana, Kenya, } \\
\text { Nigeria, Zambia, } \\
\text { Sierra Leone, } \\
\text { Switzerland South } \\
\text { Africa and Uganda }\end{array}$ & $\begin{array}{l}\text { To examine the British influence on } \\
\text { the IFRS adoption in their former } \\
\text { African colonies, in comparison to } \\
\text { other European colonies }\end{array}$ & $\begin{array}{l}\text { Most former British colonies of Africa seem to follow } \\
\text { their colonial ruler in adopting the IFRS, a trend that } \\
\text { shows the subtitle influence of Anglo-imperialism in } \\
\text { the region through the system of financial accounting } \\
\text { reporting. The Franco-German block has lesser } \\
\text { influence on their colonial countries and hence, the } \\
\text { low IFRS adoption rate in the block. }\end{array}$ \\
\hline Laga (2012) & Libya & $\begin{array}{l}\text { This paper focused on the practical } \\
\text { obstacles that will face the process of } \\
\text { implementing of International } \\
\text { Financial Reporting Standards (IFRS), } \\
\text { with particular reference to Libya }\end{array}$ & $\begin{array}{l}\text { This paper revealed that many necessary steps should } \\
\text { be taken to overcome such obstacles which include } \\
\text { strengthening professional accountancy body } \\
\text { (LAAA) to improve the status of profession, } \\
\text { revisions of curriculum for educating and training of } \\
\text { professional accountants to enable accountants to } \\
\text { gain exposure to international developments in the } \\
\text { profession including IFRS application. }\end{array}$ \\
\hline Negash (2012) & No stated & $\begin{array}{l}\text { The purpose of this paper is to } \\
\text { examine whether International } \\
\text { Financial Reporting Standards (IFRS) } \\
\text { can be used for monitoring } \\
\text { environmental degradation }\end{array}$ & $\begin{array}{l}\text { The sustainability reports produced by the companies } \\
\text { contained both information and propaganda. The } \\
\text { credibility of published sustainability reports is } \\
\text { unclear. The size and adequacy of the contributions } \\
\text { of the companies towards sharing the costs of } \\
\text { decommissioning rehabilitation and restoration of the } \\
\text { environment are not disclosed. }\end{array}$ \\
\hline Okpala (2012) & Nigeria & $\begin{array}{l}\text { To improve the effect of IFRS } \\
\text { adoption on Foreign direct Investment } \\
\text { and Nigeria economy }\end{array}$ & $\begin{array}{l}\text { IFRS has been adopted in Nigeria but only fraction of } \\
\text { companies has implemented with deadline for the } \\
\text { others to comply }\end{array}$ \\
\hline
\end{tabular}

Indonesia, one of many emerging countries does not full adopt IFRS yet, faces challenges which threaten to damage the process of the implementation of IFRS. Considerable research studies have investigated the motivations behind the adoption of IFRS by emerging nations. According to some of these studies, the decision to adopt IFRS derives from the fact that developing nations are generally unable to allocate the financial and technical resources needed to develop high-quality, indigenous accounting standards (Saidi, 2013). (See Table 1 
for a summary of key previous studies). Prior accounting researches (Irvine \& Lucas, 2006; Gyasi, 2010; Laga, 2012; Owolabi \& Iyoha, 2012; Okpala, 2012; Schachler, 2012; Mohamed, 2014) have investigated the influences of several environmental issues on implementation of IFRS. For instance, Gyasi (2010), Laga (2012), Schachler (2012), and Mohamed (2014), all mentioned that there are some challenges facing the adoption of IFRS in developing countries.

\section{Studies Related}

Various studies have been made in hope to seek on the process of IAS/IFRS adoption and its application in many countries as shown in Table 1 .

\section{Research Hypothesis Development}

IAS/IFRS and accounting literature, both theoretical and empirical, has persistently shown the effect of extra-financial factors on accounting standards development. In this respect, Belkaoui (1983) has noted that the accounting standards and policies are social products that cannot escape the influences of the institutional environment. In light of the IAS/IFRS literature adoption, Hove (1986), Chamisa (2000), Streets (2002), Standish (2003), Zeghal and Mhedhbi (2006), Al-Akra (2009), Chokri (2013), and Mohamed (2014), strive to derive a set of hypotheses that relate to studying the impact of the emerging countries' on the decision of adopting of IAS/IFRS.

\section{Legal Systems Factor}

The legal system in the developing countries is a factor that influences IFRS adoption, whereas some developing countries are affected by the legal systems of developed countries. However, the legal system in most of the Muslim countries is influenced by their religion (Islam). Therefore, their accounting system requires specific needs that are different from those in other developing countries where religion does not have a direct bearing on their accounting system and where there is a clear separation between State and religion.

The accounting disclosure may also be influenced by the legal disclosure standards (Kantor, 1995). La Porta (1997, 1998) observed the a direct relationship between legal system, level of investor protection, and capital market development, found that more importantly, legal systems have been directly associated with divulgation practices. Doupnik and Salter (1995), Jaggi and Low (2000), and Ball (2000) looked at the impact of legal system on the financial report and range in reporting incentives and earnings properties. IFRS adoption may transpose into market benefits only where there are greater incentives for better disclosure (Daske, 2008; Li, 2009). In common law countries, information asymmetry is likely to be resolved by timely and greater public disclosures to shareholders "shareholder model", whereas communication in code law countries is more likely to be conducted more privately between major political groups "stakeholder model". As a result, accounting standards in common law countries may be similar to IFRS, thus making adoption of IFRS easier and more enforceable.

H1: Emerging country with common low legal systems in shareholder protection will have a higher probability of adoption of International Financial Reporting Standards (IFRS).

\section{Taxation System Factor}

In developing countries, taxation has been testifying to influence IFRS adoption. Governments that have greater control upon managing the resources of a country, i.e., macro-economies, tend to become important 
players in shaping reporting standards (Alnajjar, 1986; Doupnik \& Salter, 1993; Xiao, 2004). Greater government overseeing of a nation's resources and economic target is bound with financial accounting rules which main purpose is oriented toward satisfying regulatory needs, such as taxation and conformity matters, instead of information needs of investors.

Financial and tax reporting conformity has been coupled with reduce in value relevance of accounting earnings (Ali \& Hwang, 2000), and a reduce in capital mobility (Young \& Guenther, 2003). Adoption of IFRS can increase costs to modify current tax enforcement systems by altering current tax calculations and financial reporting (Hail, 2010). Therefore, it is predicted that as the importance of corporate taxation increases, the likelihood of countries adoption to IFR will decrease.

H2: Emerging country where corporate taxation is more substantial for central government financing will have a lower probability of International Financial Reporting Standards (IFRS) adoption.

\section{Economic and Political Ties}

Cooke and Wallace (1990) point out those accounting standards have a strong relationship with the environmental factors including economic growth. In addition, Sedaghatet (1994) refers to the positive relationship between economic growth and accounting information in developing countries. Governments in many developing countries interfere in economic activities due to the political structure in such countries.

The degree of government implication in the country's economy would assign the accounting standards, for example if the government is the main user of the accounting information, then this would affect the accounting standards used in this country (Zeghal \& Mhedhbi, 2006). According to Saudagaran and Diga (2000), developing countries adopt IFRSs for the purpose of becoming acceptable in the international market. However, they do not aim to make fundamental changes to their political and economic strategies which could be necessary to adopt the IFRS more efficiently. Irvine and Lucas (2006) argue that UAE required its listed firms to prepare their financial statements under IFRSs on or before 2005. The adoption of IFRS in some developing countries, therefore, has become mandatory due to the external pressure or the influence of the international organizations such as the IMF and the World Bank (Hooper \& Morris, 2004). Sucher and Alexander (2004) point out that the International accounting firms (IAFs) play a significant role in developing countries to motivate them to adopt IFRSs in order to list their firms internationally.

H3: Economic and political factor ties have a positive influence on International Financial Reporting Standards (IFRS) adoption in emerging country.

\section{Accounting Education and Infrastructure}

A more highly educated population in general and particularly in accounting plays a significant role in the adoption of IFRS (Irvine \& Lucas, 2006; Abdelsalam \& Weetman, 2007). Accounting standards and practices become more complex, the ability to apply and interpret those standards and practices will depend on the educational level of the population (Choi \& Meek, 2008). A lack of adequate accounting education and infrastructure, knowledge, training, and skills especially in early started, often giving rise to improper application of the IFRS standards (Jermakowicz, 2006; Samaha \& Stapleton, 2008).

IFRS adoption is considered as an advantage over the local accounting standards whereas it would be reducing the cost of training staff (McLeay, 2000). Perera (1989) argues that information provided by developed countries' accounting standards will not afford useful information to make financial decisions in developing countries. Zeghal and Mhedhbi (2006) indicate that the need to create an active education system is one of the 
significant factors that affect the accounting standards in emerging country. Many emerging countries base their accounting education system on one of the developed countries such as UK and US GAAP where accounting education systems have had a positive relation with their national GAAP to IFRS convergence. Countries with less sophisticated educational systems may find the transition to IFRS more costly and drag to implement compared to other countries with better education systems.

H4: Emerging countries with a higher level of accounting sophisticated education system will have higher probability to adopt IFRS.

\section{Culture Structure}

Country's culture structure, values, and norms, are known to shape that society's various institutions (Hofstede, 1980; 1984). Although the construct of culture has been empirically tested in various aspects, including religion, language, and patterns of human behavior (Frank, 1979; Stulz \& Williamson, 2003). Empirical obviousness of culture's influence on accounting system development has been mixed, with marketplace and institutional variables surpassing culture in explaining extant disclosure practice (Zarzeski, 1996; Jaggi \& Low, 2000).

Hofstede (1980) and Gray (1988) identified the first cultural theory in accounting by using four dimensions in accounting such as conservatism, consistency, discretion, and professionalism. Gray (1988) established the correlation between the theoretical framework of Hofstede (1980), on accounting concepts, accounting practices, and cultural dimensions, and Baydoun (1995) found that a country where culture is oriented against uncertainty, where uniformity is very high, where there is a large power distance, and where individualism is average, shows a conservative accounting system based on social status, and taking into account the views of professionals. Thus, culture can influence judgments of professionals and therefore accounting practices to implement.

H5: Emerging countries with lower levels of uncertainty avoidance will be more probable to adopt IFRS.

\section{Research Method}

Place and Research Site: Republic of Indonesia

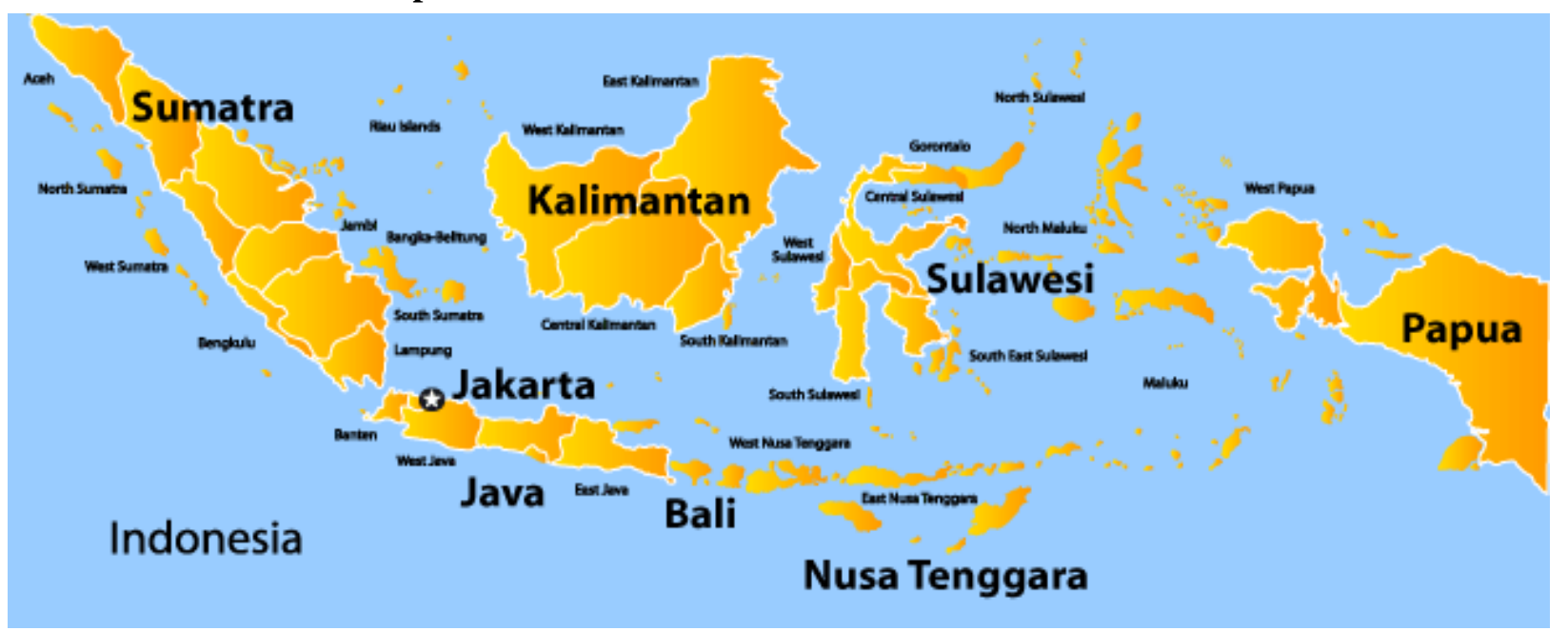

Figure 1. Map of Indonesian.

Astronomically, Indonesia is situated between $6^{\circ} 08^{\prime}$ North latitude and $11^{\circ} 15^{\prime}$ South latitude, and between $94^{\circ} 45^{\prime}$ and $141^{\circ} 05^{\prime}$ East longitude and straddles the equator line located at $0^{\circ}$ latitude line. Indonesia is the 
world's largest archipelago consisting of 17,504 islands with an area of ocean $3,544,743.9 \mathrm{~km}^{2}$ and land $1,910,931.32 \mathrm{~km}^{2}$. With a current population of 260,506,081 as of Thursday, June 23, 2016 (based on the latest United Nations estimates) or $3.5 \%$ equivalent of the total word population which make Indonesia occupy ranks number 4 in the list of countries by population. The population density in Indonesia is 144 per $\mathrm{km}^{2}$ (372 people per $\mathrm{mi}^{2}$ ) with a total land area of $1,812.108 \mathrm{~km}^{2}(699.658 \mathrm{sq}$ in 2016) and with $53.4 \%$ of the population urban $(140,824,151$ people in 2016). Approximately, 86 percent (KMPG, 2012) of the population are Muslims, making Indonesia as the world's largest Islamic country.

Under controlling of colonial Dutch for almost 350 years has influenced on the socioeconomic and political development in Indonesia. A large power distance, a considerable dependence of subordinates on superiors (Hofstede, 1980) is a colonial heritage that continues to involve in various behavioral aspects in society including legal system. As regards, Indonesian legal system is based on the Roman Dutch system, characterizing the regulation with a large extent of a law branch and only seeks to formulate a general rule for the future than provide answer to a specific case. Otherwise, the rule tends to be separated from the law and deals with a precise case in the common law countries (Nobes \& Parker, 2012). Nowadays, after experiencing with crises, Indonesia's economy is stable with GDP in 2012, at current market prices, reaching IDR 8,241,864.3 billion, or grows up around 6.2 percent compared to those on the previous year. By using a unique capitalist approach, the government continues to reform its economy aiming at deregulating it.

\section{Methodology}

To test the hypothesis on the challenges and impacts of IFRS implementation in Indonesia, we especially dedicate this section to describing the method used in this research such as the research design, the source of data, and the procedures adopted in data collection and analysis.

Research design. Due to the fact that challenges of IFRS implementation are not clearly defined, this study will be an exploratory research which aims to seek to understand more about it. Being the prime research in empirical investigation of the phenomenon in interest of Indonesia we have opts for a quantitative approach in analyzing of the research questions. We adopt in this study a survey approach through a series of questionnaires which were designed to obtain opinions about the perception on the impacts and challenges facing Indonesia to adopt IFRS. The aim of this survey was used to gather the opinions of accounting academics (lecturers, $\mathrm{PhD}$ and maters students) and practitioners in Indonesian universities regarding the effects of legal, taxation, accounting education, economic and politic ties, culture structures on adopting of IFRS in Indonesia.

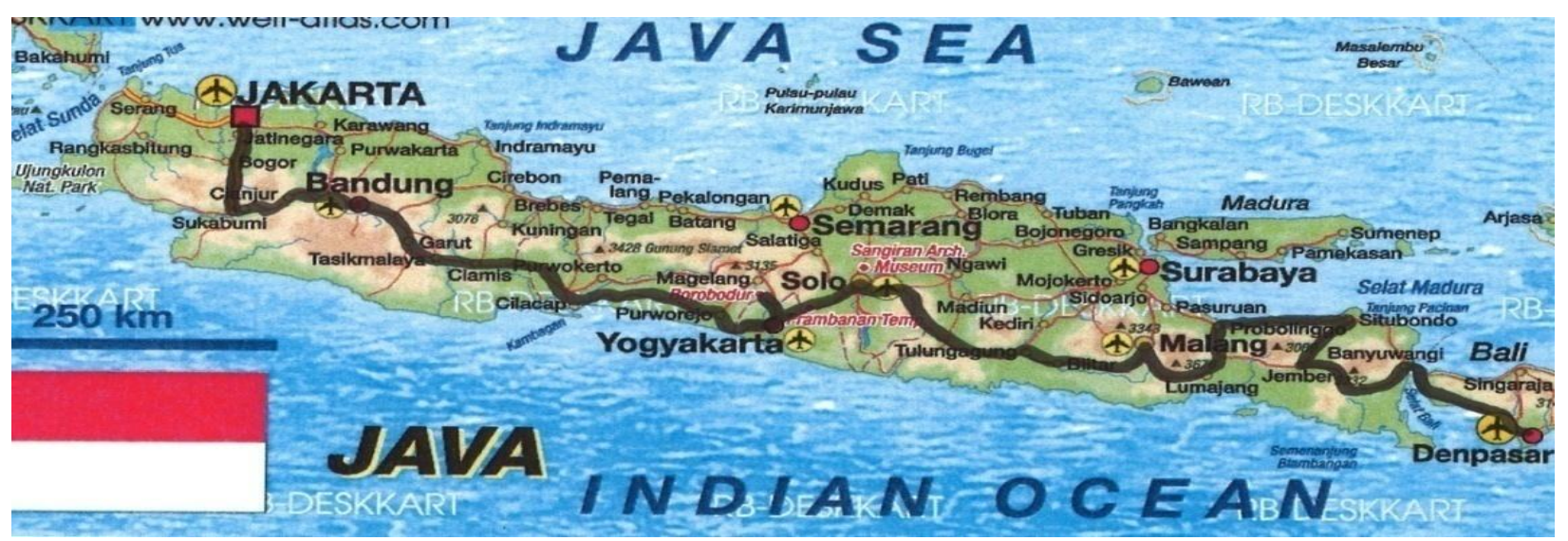

Figure 2. Map of Java Island. 
Population and sample. The population for this study includes mostly academics and practitioners in java island with a population of over 141 million (the island itself) or 145 million (Indonesia administrative region) as of 2015 Census released in December 2015, Java is home to 65 percent of the Indonesian population, and is the most populous island on Earth. The choice restriction to this Island was due to reasons of logistics and resources (both in terms of time and money).

Interactions with some lecturers and students from the universities located in this island (including the cities such as Surakarta, Jogjakarta, Semarang, Surabaya, and Malang) as well as with practitioners therein provided evidence that was somewhat convincing about the impact of legal, taxation, accounting education, economic and politic ties, culture structures on adopting of IFRS in Indonesia, despite Indonesian Government's announcement of IFRS adoption by January 2012 and IAI institution efforts. Thus, it is not expected that the conclusions of this study will be markedly different from those of a wider population of similar respondents, while this does not understand a wide coverage of the phenomenon of interest to extend our understanding of IFRS implementation issues.

Sample size and sampling technique. To collect the data regarding the IFRS issues in Indonesia and test the study hypothesis, we set a total of hundred (100) questionnaires to run it. The number of questionnaires was provided to each university according to the population of lecturers and students in this field and to the practitioners according to the population of practitioners in each city who was available to answer our research questionnaires basically to garner external and internal validities in our extra-financial analyzing regarding the issue of IFRS implementation in Indonesia.

Furthermore, it is expected that the more the sample size of academics from different universities is, the greater chances of reducing any potential bias in their responses. Non probability sampling specifically convenience sampling which refers to the collection of information from members of the population who are conveniently available to provide it and also is the best way of getting some basic information quickly and efficiently.

Sources of data and instrument of data collection. For purposes of questionnaire, the first part was designed to obtain some personal information of respondents relating to their background. The second section to obtain the opinions of accounting staff members and academic regarding the effects of legal, taxation, accounting education, economic and politic ties, and culture structures on adopting of IFRS in Indonesia. The third section was an open question to enable our respondents to afford the researchers with additional information which they felt would help the study and to identify any missing subject topics which should be considered in this study.

As recognized by the IAI that all students or whose hold a bachelor in accounting can exercise accounting profession which means that our respondents are all professionally qualified and may hold professional opinions on the issues to rise in the questionnaire.

Technics for data processing and analysis. The technique of Likert-type scales which is often used with 5-point scales (Bernard, 2000) will be undertaking for a data collection in this study. The reasons behind employing Likert-type scales are: (a) it is useful to obtain respondent's feelings or opinions (Mitchell \& Jolley, 2009), and (b) to give participants a range of options as shown in Table 2 below to choose and therefore increase the response rate. To test our study hypothesis, the SPSS (Statistical Package for Social Science) Version 18 was used to analyze the data and test the hypotheses by using appropriate statistical tools, such as frequency analyses and descriptive statistics. 
Table 2

Five Points Scales

\begin{tabular}{llllll}
\hline & Strongly disagree (SD) & Disagree (D) & Neither (N) & Agree (A) & Strongly agree (SA) \\
\hline Items & 1 & 2 & 3 & 4 & 5 \\
\hline
\end{tabular}

Several studies which were aiming at IFRS implementation such as Irvine and Lucas (2006), Laga (2012), Owolabi and Iyoha (2012), Okpala (2012), Schachler (2012), Saidi (2013), and Masoud (2014) highlight a number of variables that impact on adoption of IFRS in developing nations, among, legal system; accounting education and infrastructure; economic and political ties; culture structure, and taxation system. The majority of IFRS literature is based in developed countries as Laga (2012), Zakari (2013), and Saidi (2013) mentioned, very few studies are available on accounting in general and IFRS particularly in the emerging economics such as Indonesia. Therefore, Figure 3 shows the interconnectivity between the independent variables regarding to the extra-financial factors and the dependent factor of IFRS in this study.

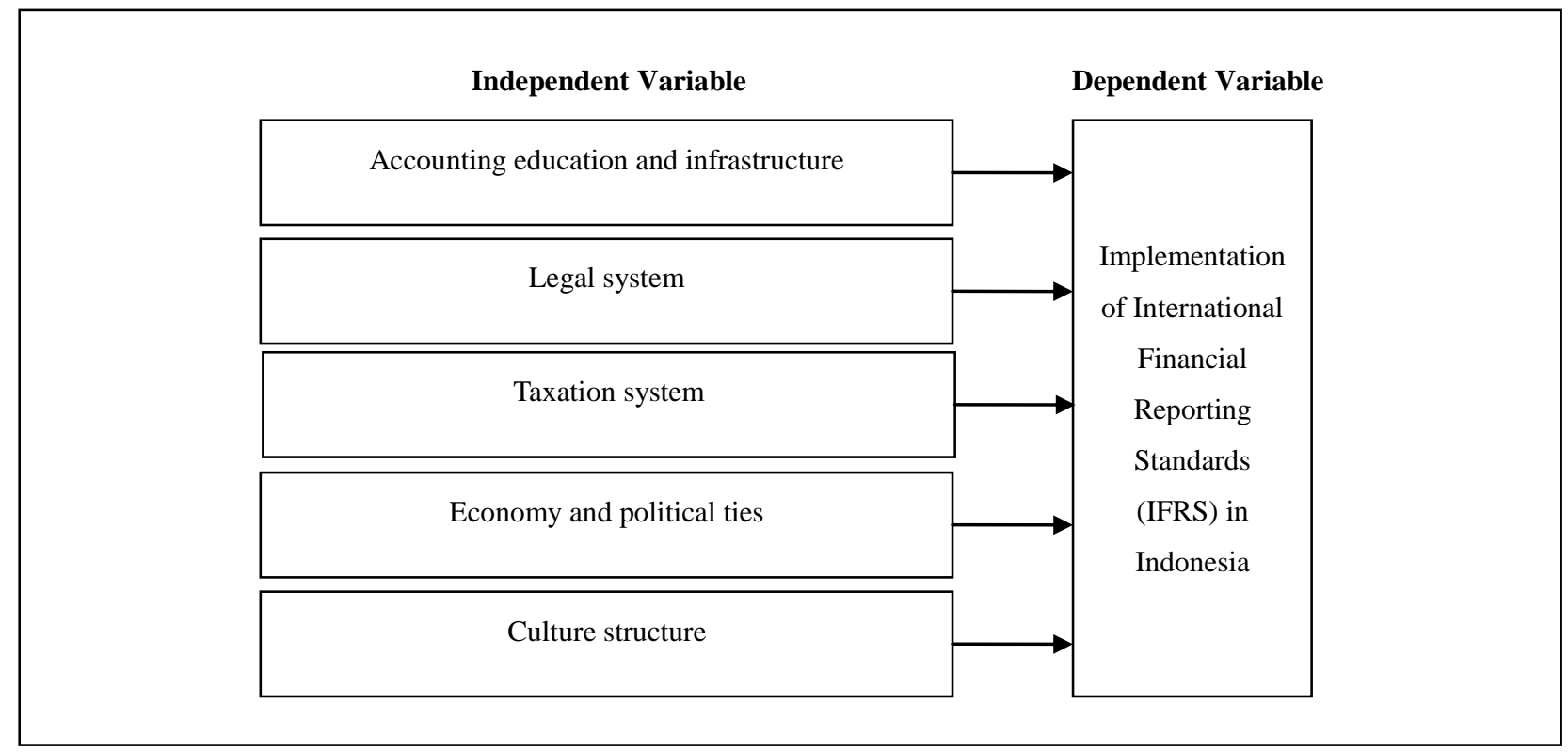

Figure 3. Theoretical framework of the study.

\section{Results and Discussion}

This part summarizes the empirical results and discusses the finding of our hypothesis proposed in chapter two.

\section{Participant's Background}

This section discusses the finding results regarding participant's background. Descriptive statistical analysis of the information regarding participant's background; participant's occupation showed in Table 3 that $41 \%$ of survey participant are university students of undergraduate and post graduate program in accounting and finance. And 32.3\% are universities lecturers in accounting and finance, 26.0\% of the respondents are accounting practitioner such as accountant, auditor, and financier. It is very interesting to note that the majority of the respondents $75 \%$ were academic including accounting and financial management lecturers and accounting and financial students of undergraduate and postgraduate. 
These results are encouraging that the amount of participant is academy $75 \%$ who are able to fully carry over Indonesian IFRS adoption.

Table 3

Percentage Distribution Results of Participant's Occupation

\begin{tabular}{lll}
\hline \multirow{2}{*}{ Participants occupation } & \multicolumn{2}{c}{ Elements } \\
\cline { 2 - 3 } & Number & Percentage \\
\hline Student & 40 & 41.7 \\
Lecturer & 31 & 32.3 \\
Practitioner & 25 & 26.0 \\
Total & 96 & 100 \\
\hline
\end{tabular}

In this second phase, descriptive statistical analysis was undertaken to analyze the information concerning our respondent's background: participant's years of experience. Table 4 below showed that $50.0 \%$ of the participants have less than two years $(<2)$ of experience in IFRS while $10.4 \%$ have more than five years $(>5)$ of experience in IFRS. These results (50\% of participants have less than two years of experience) in Table 4 confirmed that the majority of our respondents were International Accounting Standards learners.

Table 4

Percentage Distribution Results of Participant's Years of Experience

\begin{tabular}{llc}
\hline \multirow{2}{*}{ Participants years of experience in IFRS } & \multicolumn{2}{c}{ Elements } \\
\cline { 2 - 3 } & Number & Percentage \\
\hline$<2$ years & 48 & 50.0 \\
$2-5$ years & 38 & 39.6 \\
More than 5 years & 10 & 10.4 \\
Total & 96 & 100 \\
\hline
\end{tabular}

The third part of our survey questionnaires regarding respondent's background was participant's level of education. Descriptive statistical analysis of the information regarding participant's level of education showed in Table 5 below that $47.9 \%$ of all participants had their first university degree, $31.3 \%$ had their master degree, and $20.8 \%$ their PHD degree.

These results are interesting to note that the majority of respondents with level of education master and PHD degree were universities lecturers in accounting and finance and some of them had followed the transition training of Indonesian GAAP convergence to IFRS organized by Institute of Indonesia chartered Accountants (Ikatan Akuntan Indonesia (IAI)).

Table 5

Percentage Distribution Results of Participant's Level of Education

\begin{tabular}{lll}
\hline \multirow{2}{*}{ Participants level of education } & \multicolumn{2}{c}{ Elements } \\
\cline { 2 - 3 } & Number & Percentage \\
\hline First university degree & 46 & 47.9 \\
Master degree & 30 & 31.3 \\
PHD degree & 20 & 20.8 \\
Total & 96 & 100 \\
\hline
\end{tabular}

\section{Participants Perception Regarding IFRS Adoption and Implementation in Indonesia}

Cronbach's Alpha test was used to test the reliability of all items in the scales and to measure internal 
consistency for the research survey questionnaires, based on the sample estimation. In spite of the fact that George and Mallery (2003) had suggested that 0.7 , as the accepted level, a value more than 0.6 is regarded as a satisfactory level (Pallant, 2007). The reliability test of our research survey questionnaire was conducted for all 22 items. According to Sekaran (1992), "The reliability of a scale indicates the stability and consistency with which the instrument is measuring the concept and helps to assess the goodness of a measure". The reliability test using Cronbach's alpha was conducted after coding all answers from completed questionnaires. The results indicated that Cronbach's alpha was 0.810 which is acceptable in social science research (Field, 2009). Consequently, the inter-item consistency reliability (ICR) measurement which has been used in this research may be considered as very acceptable.

The summary of item statistics means for all survey item showed that the overall means $(\mu=3.657)$ with a minimum of 2.927 and a maximum of 3.990. These results confirmed that the extra-financial factors including legal system, taxation system, economic and political ties, culture structure, and accounting education and infrastructures impact Indonesia companies in their IAS/IFRS adoption and application.

Overall means $(\mu=3.657)$ also show that the participants agree that the extra-financial factor including:

Legal system. At this stage, see Table 6, we propose to examine the relation of Indonesian regulation as an impact on the decision to adopt IFRS. It was agreed by the respondents that Inconsistency of existing laws and regulatory frameworks of accounting with recent development of accounting profession affect IFRS implementation in Indonesia $(\mu=3.84$ with a high level of agree and strongly agree, 83.3\%); our respondents rate the item lacks of an independent oversight body to monitor and enforce accounting and auditing standards and codes affect Indonesia to fulfill IFRS implementation with a means $(\mu=3.76)$ and $75 \%$ of level of agree and strongly agree. Legal system as an challenge for IAS/IFRS application by Indonesian companies nevertheless the results show a higher mean of satisfaction "Indonesia IFRS adaptation gives firms an incentive to have more corporate social responsibility among firm's stakeholders" $(\mu=3.84)$ with a high level of $79.2 \%$ agree and strongly agree.

Table 6

Results of Participants Perceptions About the Relation of Legal System Factor to Indonesian IFRS Adoption and Application

\begin{tabular}{|c|c|c|c|c|c|c|c|c|c|c|c|c|}
\hline \multicolumn{13}{|c|}{ Legal system factor } \\
\hline \multirow{2}{*}{ Code } & \multicolumn{2}{|c|}{ SD } & \multicolumn{2}{|c|}{$\mathrm{D}$} & \multicolumn{2}{|c|}{$\mathrm{N}$} & \multicolumn{2}{|c|}{ A } & \multicolumn{2}{|c|}{ SA } & \multirow{2}{*}{-Mean } & \multirow{2}{*}{ Std. deviation } \\
\hline & $\overline{\mathrm{N}_{\mathrm{O}}}$ & $\%$ & $\mathrm{~N}_{\mathrm{O}}$ & $\%$ & $\mathrm{~N}_{\mathrm{O}}$ & $\%$ & $\mathrm{~N}_{\mathrm{O}}$ & $\%$ & $\mathrm{~N}_{\mathrm{O}}$ & $\%$ & & \\
\hline Q1 & 1 & 1 & 4 & 4.2 & 11 & 11.5 & 73 & 76 & 7 & 7.3 & 3.84 & 0.654 \\
\hline Q2 & 1 & 1 & 24 & 25 & 32 & 33.3 & 35 & 36.5 & 4 & 4.2 & 3.18 & 0.894 \\
\hline Q3 & 3 & 3.1 & 28 & 29.2 & 38 & 39.6 & 27 & 28.1 & 0 & 0 & 2.93 & 0.837 \\
\hline Q4 & 1 & 1 & 3 & 3.1 & 16 & 16.7 & 66 & 68.8 & 10 & 10.4 & 3.84 & 0.686 \\
\hline Q5 & 0 & 0 & 7 & 7.3 & 17 & 17.7 & 64 & 66.7 & 8 & 8.3 & 3.76 & 0.707 \\
\hline
\end{tabular}

Taxation system. The results show in Table 7 that respondents to the questionnaires Indonesia IFRS adaptation increase government currency savings with a means $(\mu=3.46)$ and participants rate agree and strongly agree of 54.2\%; additionally, it was believed by the respondents that "Indonesia IFRS adaptation is a part of globalization process and applies globalization concepts $(\mu=3.93)$ " and a high level of $82.3 \%$ agree and strongly agree. 
Table 7

Results of Participants Perceptions About the Relation of Taxation System Factor to Indonesian IFRS Adoption and Application

\begin{tabular}{|c|c|c|c|c|c|c|c|c|c|c|c|c|}
\hline \multicolumn{13}{|c|}{ Taxation system factor } \\
\hline \multirow{2}{*}{ Code } & \multicolumn{2}{|c|}{ SD } & \multicolumn{2}{|c|}{$\mathrm{D}$} & \multicolumn{2}{|c|}{$\mathrm{N}$} & \multicolumn{2}{|c|}{ A } & \multicolumn{2}{|c|}{ SA } & \multirow{2}{*}{-Mean } & \multirow{2}{*}{ Std. deviation } \\
\hline & $\mathrm{N}_{\mathrm{O}}$ & $\%$ & $\mathrm{~N}_{\mathrm{O}}$ & $\%$ & $\mathrm{~N}_{\mathrm{O}}$ & $\%$ & $\mathrm{~N}_{\mathrm{O}}$ & $\%$ & $\mathrm{~N}_{\mathrm{O}}$ & $\%$ & & \\
\hline Q6 & 1 & 1 & 12 & 12.5 & 31 & 32.3 & 46 & 47.9 & 6 & 6.3 & 3.46 & 0.832 \\
\hline Q7 & 0 & 0 & 12 & 12.5 & 41 & 42.7 & 35 & 36.5 & 8 & 8.3 & 3.41 & 0.815 \\
\hline Q8 & 1 & 1 & 4 & 4.2 & 12 & 12.5 & 63 & 65.6 & 16 & 16.7 & 3.93 & 0.743 \\
\hline
\end{tabular}

Economic and political ties. The respondents rate these items "Indonesia IFRS adaptation is a type of following business globalization with a means $(\mu=3.94)$ " and a high level of $76.1 \%$ agree and strongly agree; the participants rate also "IFRS" standards are set to comply political, social, and economic aims in Indonesia with a means $(\mu=3.60)$ and $63.6 \%$ of level agree and strongly agree (Table 8$)$.

Table 8

Results of Participant's Perceptions About the Relation of Economic and Political Ties Factor to Indonesian IFRS Adoption and Application

\begin{tabular}{|c|c|c|c|c|c|c|c|c|c|c|c|c|}
\hline \multicolumn{13}{|c|}{ Economic and political ties } \\
\hline \multirow{2}{*}{ Code } & \multicolumn{2}{|c|}{ SD } & \multicolumn{2}{|r|}{$\mathrm{D}$} & \multicolumn{2}{|c|}{$\mathrm{N}$} & \multicolumn{2}{|c|}{$\mathrm{A}$} & \multicolumn{2}{|c|}{ SA } & \multirow{2}{*}{ Mean } & \multirow{2}{*}{ Std. deviation } \\
\hline & $\mathrm{N}_{\mathrm{O}}$ & $\%$ & $\mathrm{~N}_{\mathrm{O}}$ & $\%$ & $\mathrm{~N}_{\mathrm{O}}$ & $\%$ & $\mathrm{~N}_{\mathrm{O}}$ & $\%$ & $\mathrm{~N}_{\mathrm{O}}$ & $\%$ & & \\
\hline$\overline{\text { Q9 }}$ & 0 & 0 & 4 & 4.2 & 19 & 19.8 & 52 & 54.2 & 21 & 21.9 & 3.94 & 0.765 \\
\hline Q10 & 3 & 3.1 & 19 & 19.8 & 26 & 27.1 & 39 & 40.6 & 9 & 9.4 & 3.33 & 1.002 \\
\hline Q11 & 2 & 2.1 & 15 & 15.6 & 24 & 25 & 46 & 47.9 & 9 & 9.4 & 3.47 & 0.94 \\
\hline Q12 & 1 & 1 & 8 & 8.3 & 26 & 27.1 & 54 & 56.3 & 7 & 7.3 & 3.6 & 0.788 \\
\hline Q13 & 0 & 0 & 9 & 9.4 & 31 & 32.3 & 42 & 43.8 & 14 & 14.6 & 3.64 & 0.848 \\
\hline
\end{tabular}

Culture structure. Table 9 shows the results from the respondents regarding the needs of sound ethical environment in business field pushed Indonesia to implement IFRS with a means $(\mu=3.78)$ and a level of $71.8 \%$ agree and strongly agree; Indonesia IFRS adaptation encourages the society to achieve economic goals with a means $(\mu=3.74)$ and $68.8 \%$ of agree and strongly agree rate; more ever respondents give a high level to the questionnaire "Indonesia IFRS adaptation encourages firms to increase employee's education efforts and make them active elements in society development" with a means $(\mu=3.73)$ and $68.8 \%$ of level agree and strongly agree.

Table 9

Results of Participant's Perceptions About the Relation of Culture Structure to Indonesian IFRS Adoption and Application

\begin{tabular}{|c|c|c|c|c|c|c|c|c|c|c|c|c|}
\hline \multicolumn{13}{|c|}{ Culture structure } \\
\hline \multirow{2}{*}{ Code } & \multicolumn{2}{|c|}{ SD } & \multicolumn{2}{|c|}{$\mathrm{D}$} & \multicolumn{2}{|c|}{$\mathrm{N}$} & \multicolumn{2}{|c|}{$\mathrm{A}$} & \multicolumn{2}{|c|}{ SA } & \multirow{2}{*}{-Mean } & \multirow{2}{*}{ Std. deviation } \\
\hline & $\mathrm{N}_{\mathrm{O}}$ & $\%$ & $\mathrm{~N}_{\mathrm{O}}$ & $\%$ & $\mathrm{~N}_{\mathrm{O}}$ & $\%$ & $\mathrm{~N}_{\mathrm{O}}$ & $\%$ & $\mathrm{~N}_{\mathrm{O}}$ & $\%$ & & \\
\hline Q14 & 0 & 0 & 14 & 14.6 & 31 & 32.3 & 42 & 43.8 & 9 & 9.4 & 3.48 & 0.858 \\
\hline Q15 & 0 & 0 & 7 & 7.3 & 23 & 24 & 55 & 57.3 & 11 & 11.5 & 3.73 & 0.761 \\
\hline Q16 & 0 & 0 & 7 & 7.3 & 23 & 24 & 54 & 56.3 & 12 & 12.5 & 3.74 & 0.771 \\
\hline Q17 & 0 & 0 & 2 & 2.1 & 25 & 26 & 61 & 63.5 & 8 & 8.3 & 3.78 & 0.619 \\
\hline
\end{tabular}


Accounting education and infrastructure. The respondents rate these five questionnaires with a higher means grading to approve that accounting education and infrastructure as an impact of Indonesia IAS/IFRS adoption and application (see Table 10).

Table 10

Results of Participant's Perceptions About the Relation of Accounting Education and Infrastructure to Indonesian IFRS Adoption and Application

\begin{tabular}{|c|c|c|c|c|c|c|c|c|c|c|c|c|}
\hline \multicolumn{13}{|c|}{ Accounting education and infrastructure } \\
\hline \multirow{2}{*}{ Code } & \multicolumn{2}{|c|}{ SD } & \multicolumn{2}{|r|}{$\mathrm{D}$} & \multicolumn{2}{|c|}{$\mathrm{N}$} & \multicolumn{2}{|c|}{ A } & \multicolumn{2}{|c|}{ SA } & \multirow{2}{*}{ Mean } & \multirow{2}{*}{ Std. deviation } \\
\hline & $\overline{N_{O}}$ & $\%$ & $\mathrm{~N}_{\mathrm{O}}$ & $\%$ & $\mathrm{~N}_{\mathrm{O}}$ & $\%$ & $\mathrm{~N}_{\mathrm{O}}$ & $\%$ & $\mathrm{~N}_{\mathrm{O}}$ & $\%$ & & \\
\hline $\bar{Q} 18$ & 0 & 0 & 7.3 & 7.7 & 20 & 20.8 & 54 & 56.3 & 15 & 15.6 & 3.8 & 0.79 \\
\hline Q19 & 0 & 0 & 6 & 6.3 & 18 & 18.8 & 52 & 54.2 & 20 & 30.8 & 3.9 & 0.801 \\
\hline Q20 & 1 & 1 & 2 & 2.1 & 13 & 13.5 & 61 & 63.5 & 19 & 19.8 & 3.99 & 0.718 \\
\hline Q21 & 1 & 1 & 5 & 5.2 & 18 & 18.8 & 57 & 59.4 & 15 & 15.6 & 3.83 & 0.79 \\
\hline Q22 & 0 & 0 & 8 & 8.3 & 23 & 24 & 38 & 39.6 & 27 & 28.1 & 3.88 & 0.921 \\
\hline
\end{tabular}

\section{Result Summary}

The empirical analysis of the research items in sections 4.7, 4.8, 4.9, 4.10, and 4.11 have provided answers to our research hypothesis showed in Table 11 below.

Table 11

Summary of Hypothesis and Finding

\begin{tabular}{|l|l|l|l|}
\hline No & Objectives & Hypothesis & Finding \\
\hline 1 & $\begin{array}{l}\text { To know if Indonesia common law regarding } \\
\text { accounting standard is similar to IFRS thus making } \\
\text { adoption of IFRS easier and more enforceable. }\end{array}$ & $\begin{array}{l}\text { Emerging country with common low legal systems in } \\
\text { shareholder protection will have a higher probability } \\
\text { of adoption of International Financial Reporting } \\
\text { Standards (IFRS). }\end{array}$ & Support \\
\hline 2 & $\begin{array}{l}\text { To investigate if Indonesia central Government } \\
\text { significantly depending on corporate tax which can } \\
\text { impact IFRS adoption and application by Indonesia } \\
\text { companies. }\end{array}$ & $\begin{array}{l}\text { Emerging country where corporate taxation is more } \\
\text { substantial for central government financing will have } \\
\text { a lower probability of International Financial } \\
\text { Reporting Standards (IFRS) adoption. }\end{array}$ & Support \\
\hline 3 & $\begin{array}{l}\text { To examine if political and economy ties significantly } \\
\text { impacted Indonesia IFRS adoption. }\end{array}$ & $\begin{array}{l}\text { Economic and political factor ties have a positive } \\
\text { influence on International Financial Reporting } \\
\text { Standards (IFRS) adoption in emerging country. }\end{array}$ & Support \\
\hline 4 & $\begin{array}{l}\text { To under seek if Indonesia accounting curriculum is } \\
\text { strongly sophisticated thus making easy Indonesia } \\
\text { GAAP transition to IFRS. }\end{array}$ & $\begin{array}{l}\text { Emerging countries with a higher level of accounting } \\
\text { sophisticated education system will have higher } \\
\text { probability to adopt IFRS. }\end{array}$ & Support \\
\hline 5 & $\begin{array}{l}\text { To examine to level Indonesia culture oriented on } \\
\text { uncertainty avoidance which can impact IFRS } \\
\text { adoption and application. }\end{array}$ & $\begin{array}{l}\text { Emerging countries with lower levels of uncertainty } \\
\text { avoidance will be more probable to adopt IFRS. }\end{array}$ & Support \\
\hline
\end{tabular}

\section{Discussion}

The summary of hypothesis and finding indicate that the results support the entire five research hypotheses. Inconsistency of existing laws and regulatory frameworks of accounting with recent development of accounting profession affect IFRS implementation in Indonesia. This finding supports hypothesis one and is consistent with the findings of Gyasi (2010) and Mohamed (2014) who found that legal system affects IFRS adoption in developing countries. Kim M. and David C. (2012) find the results which confirmed a negative and less significant relation of taxation system with IFRS adoption (results unstipulated) which is inconsistent with our finding therefore, the study conducted by Lega (2012) concluded that legal system affects IFRS implementation in developing countries, which is consistent with our finding. This finding supports the hypothesis two (2). 
Irvine and Lucas (2006), Mohamed (2014), Schachler (2012), Irvine and Lucas (2006), Judge and Pinsker (2010), Schachler (2012), and Mohamed (2014) all had in some pathway in their research relating to IFRS adoption in developing countries and found that the factors such as economy and political ties, accounting education, and culture structure are the main challenges of international accounting standards adoption and implementation in developing though developed countries. These findings are consistent with this research finding by supporting the hypotheses 3,4 , and 5 .

\section{Conclusion and Recommendation}

Since these standards are new and unfamiliar to Indonesia accounting local staff, several training must be done to ensure that these accountants are adept with handling these new standards. This invariably leads to increase in the cost of training. Also, the services of consultants must be purchased so as to complete compliance with the new standards adopted which also increases the consultancy cost immensely. Merely IFRS adoption is not enough, important links could exist in the enforcement sequences including: (a) directors and top management must ensure that financial statements are prepared in compliance with established standards; (b) auditors must act independently and judiciously to ensure that financial statements comply with applicable accounting standards and represent a true and fair position of the enterprise's financial condition; and (c) regulators, both self-regulatory organizations and statutory regulators, must implement arrangements for efficient monitoring of regulatory compliance and consistently take appropriate actions against violators (Wickramasinghe, 2015). IAI, Indonesian Government, business owners, accounting body, accounting institutions and academic to bring all companies listed or unlisted to embrace and fulfill IFRS adoption should follow the recommendations as followed:

Establishment of Financial Monitoring Board: The government takes act to reinforce the independent oversight body named Ikatan Akuntan Indonesia (IAI) to support the responsibility of setting accounting and auditing standards, monitoring compliance with accounting standards, reviewing auditors' practice, reviewing reporting practices, and enforcing sanctions for violations. Government should also ensure the capacity and effectiveness of its regulatory regime by providing a real sense of security to stakeholders. The IAI should focus on technically qualified personnel, practical training of inspectors/reviewers, administrative support, and necessary logistics arrangements. The IFRS enforcement bodies, Indonesian accounting institute should immediately enhance their expertise.

Inclusion of other interested parties: A system for adoption of standards and monitoring must be developed to work on a consensus view of all the interested parties. Apart from that, Exposure Drafts are to be circulated for comments from various professionals and the general public at large. This often has the result of minimizing dissension and thus increasing acceptance of accounting standards developed by the committee (Hove, 1990).

Encouraging the firms for adopting IFRS: On the basis of proper compliance of IFRS, the regulatory authorities can provide significant benefits (like, firms reporting regularly complying IFRS and other necessary requirement will have relax listing criteria or incentives in either monetary or non-monetary forms).

Role of government: The government should introduce an awareness program for improving the degree of compliance with accounting requirements by specified business enterprises. IAI and Indonesian accounting institutions should work jointly to design an awareness program on the importance of compliance with accounting and auditing requirements. 
Upgrading accounting curriculum: In order to ensure a minimum quality standard in teaching accounting and auditing courses in all Indonesian universities, an initiative is necessary for a sophisticated curriculum development and training-the-trainers activities.

\section{References}

Abd El-Razik, A. (2009). Challenges of international financial reporting standards (IFRS) in the Islamic accounting world, case of middle eastern countries. Scientific Bulletin Economic Sciences, 8(14). Retrieved from http://economic.upit.ro/repec/pdf/F2_Amged_Razik.pdf

Al-Akra, M., Jahangir, A. B., \& Marashdeh, A. (2009). Development of accounting regulation in Jordan. The International Journal of Accounting, 44, 163-186.

Ali, A., \& Hwang, L. (2000). Country-specific factors related to financial reporting and the value relevance of accounting data. Journal of Accounting Research, 38(1), 1-21.

Al-Najjar, \& Fouad, K. (1986). Standardisation in accounting practices, a comparative international study. The International Journal of Accounting, 21, 161-176.

Ball, R., Kothari, S., \& Robin, A. (2000). The effects of international institutional factors on properties of accounting earnings. Journal of Accounting and Economics, 29, 1-51.

Bernard, H. R. (2000). Social research methods: Qualitative and quantitative approaches. Thousand Oaks, CA: Sage Publications.

Belkaoui, A. (1983). Economic, political, and civil indicators and reporting and disclosure adequacy: Empirical investigation. Journal of Accounting and Public Policy, 2(3), 207-219.

Cerne, K. (2009). Influential factors of country's accounting system development. Economic Research Journal, 22(2), 66-97.

Chamisa, E. (2000). The relevance and observance of the IASC standards in developing countries and the particular case of Zimbabwe. The International Journal of Accounting, 35(2), 267-286.

Choi, F., \& Meek, G. (2008). International Accounting (6th ed.). Upper Saddle River, NJ: Pearson Education Inc.

Cooke, T., \& Wallace, R. (1990). Financial disclosure regulation and its environment: A review and further analysis. Journal of Accounting and Public Policy, 9, 79-110.

Daske, H., Hail, L., Leuz, C., \& Verdi, R. (2007). Mandatory IFRS reporting around the world: Early evidence on the economic consequences. Journal of Accounting Research, 46(5), 1085-1142.

Doupnik, T., \& Salter, S. (1995). External environment, culture, and accounting practice: A preliminary test of a general model of international accounting development. The International Journal of Accounting, 30, 189-207.

Faraj, S., \& Akbar, S. (2010). An empirical investigation of the Libyan audit market: Perceptions of auditor's independence. Journal for Global Business Advancement, 3(2), 133-154.

Field, A. (2009). Discovering statistics (3rd ed.). California, USA: Sage Publications.

Gyasi, A. (2010). Adoption of international financial reporting standards in developing countries - The case of Ghana. BSc Dissertation, University of Applied Sciences.

Hail, L., Leuz, C., \& Wysocki, P. (2010). Global accounting convergences and the potential adoption of IFRS by the U.S. (Part I): Conceptual underpinnings and economic analysis. Accounting Horizons, 24(3), 355-394.

Hassan, O., Romilly, P., Giorgioni, G., \& Power, D. (2009). The value relevance of disclosure: Evidence from the emerging capital market of Egypt. The International Journal of Accounting, 44(1), 79-102.

Hibbard, R. (2012). Global implementation of IFRS. Unpublished PhD dissertation, University of Tennessee Honors.

Hove, M. (1986). The Anglo-American influence on international accounting standards: The case of the disclosure standards of the international accounting standards committee. Research in Third World Accounting, 1, 55-66. http://papers.ssrn.com/sol3/papers.cfm?abstract_id=1024240

Hove, M. (1990). The Anglo-American influence on International Accounting Standards: The case of the disclosure standards of the International Accounting Standards Committee. Research in Third World Accounting, 1, 55-66.

Hofstede, G. (1980). Culture's consequences: International differences in work-related values. London: Sage Publications.

Ikatan Akuntan Indonesia. (2012). Daftar Standar Akuntansi Keuangan Berlaku. Retrieved from http://www.iaiglobal.or.id at 1/1 12012

International Financial Reporting Standard (IFRS). An AICPA backgrounder. Available online at http://www.ifrs.com/pdf/ifrsupdate_v8.pdf 
International Financial Reporting Standards (IFRS) Foundation. (2010). About the international financial reporting standards (IFRS) foundation and IASB. Available online at http://www.iasb.org/The+organisation/IASCF+and+IASB.htm

Irvine, H., \& Lucas, N. (2006). The globalization of accounting standards: The case of the United Arab Emirates. Working paper, 3rd International Conference on Contemporary Business, Charles Sturt University, Australia.

Jaggi, B., \& Low, P. (2000). Impact of culture, market forces, and legal system on financial disclosures. The International Journal of Accounting, 35(4), 495-519.

Jermakowicz, E. K., \& Gornik-Tomaszewski, S. (2006). Implementing international financial reporting standards from the perspective of European publicly traded companies. Journal of International Accounting, Auditing and Taxation, 15(2) (the top article in the Journal: Oct.-Dec. 2006 ScienceDirect).

Kholeif, A. (2008). A New Institutional Analysis of IFRS Adoption in Egypt: A case study of loosely coupled rules and routines. Working paper, School of Accounting, Finance and Management, University of Essex, UK.

Kim, M., \& David, C. (2012). Factors affecting the adoption of IFRS. International Journal of Business, 17(3).

La Porta, R., Lopez-de-Silanes, F., Shleifer, A., \& Vishny, R. (1997). Legal determinants of external finance. The Journal of Finance, 52(3), 1131-1150.

La Porta, R., Lopez-de-Silanes, F., Shleifer, A., \& Vishny, R. (1998). Law and finance. Journal of Political Economy, 106(6), 1113-1155.

Laga, M. (2012). Obstacles of Adopting and implementation of IFRS in Libya. European Journal of Business and Economics, 7 , 1-3. Available online at www.journals.cz/

Li, S. (2009). Does mandatory adoption of international financial reporting standards in the European Union reduce the cost of equity capital? Working paper, Santa Clara University.

Mcleay, S., Ordelheide, D., \& Young, S. (2000). Constituent lobbying and its impact on the development of financial reporting regulations: Evidence from Germany. Accounting, Organizations and Society, 25(1), 79-98.

Michas, P. (2010). Auditing in emerging market countries: Does it matter? Working Paper, University of Missouri.

Mohamed, A. Z. (2014). Challenges of international financial reporting standards (IFRS). Adoption in Libya, 4(2). Available online at http://www.macrothink.org/journal/index.php/ijafr/article/viewFile/6302/_51

Mitchell, M., \& Jolley, J. (2009). Research design explained (7th ed.). Cengage Learning.

Nobes, C., \& Parker, R. (2012). Comparative international accounting. Prentice Hall.

Ozu, C. (2000). Epidemiological aspect of accounting systems. International Transfer of Accounting Technology in the French Speaking World, 1-15.

Okpala, K. (2012). Adoption of IFRS and financial statements effects: The perceived implications on FDI and Nigeria economy. Australian Journal of Business and Management Research, 2(5), 76-83.

Owolabi, A., \& Iyoha, F. O. (2012). Adopting international financial reporting standards (IFRS) in Africa: Benefits, prospects and challenges. African J. Accounting, Auditing and Finance (AJAAF), 1(1), 77-86.

Pallant, J. (2007). SPSS survival manual: A step by step guide to data analysis using SPSS for windows (version 15) (3rd ed.). Maidenhead, UK.

Perera, H., \& Baydoun, N. (2007). Convergence with international financial reporting standards: The case of Indonesia. Advances in International Accounting, 20, 201-224.

Saidi, F. (2013). Accounting developments in Algeria: The road to IFRS. International Research Journal of Applied Finance, 4(1), 124-142.

Saudagaran, S., \& Diga, J. (2000). The institutional environment of financial reporting regulation in ASEAN. The International Journal of Accounting, 35(1), 1-26.

Schachler, M., Al-Abiyad, S., \& Al-Hadad, A. (2012). Evaluation of the suitability of international financial reporting standards (IFRSs) for application in emerging North African countries: A literature review and a research agenda. Journal of Modern Accounting and Auditing, 8(12), 1773-1779.

Sedaghat, A. M., Sagafi-nejadb, T., \& Wright, G. (1994). Economic development and securities markets in developing countries: Implications for international accounting. The International Journal of Accounting, 29(4), 297-315.

Samaha, K., \& Stapleton, P. (2008). Compliance with international accounting standards in a national context: Some empirical evidence from the Cairo and Alexandria stock exchanges. Afro-Asian Journal of Finance and Accounting, 1(1), 4066.

Soderstrom, N. S., \& Sun, K. J. (2007). IFRS adoption and accounting quality: A review. European Accounting Review, 16, $675-702$.

Street, D. (2002). GAAP benchmarking national accounting standards against IAS: Summary of results. Journal of International Accounting, Auditing \& Taxation, 11, 77-90. 
World Bank, Report on Country Observations of Standards and Codes (ROSC) 2000-2007. Washington D.C.: International Bank for Reconstruction and Development/World Bank.

Watts, R. L. (1977). Corporate financial statements, a product of the market and political processes. Australian Journal of Management, 53-75.

Watts \& Zimmerman. (1986). Positive accounting theory. Englewood Cliffs, NJ: Prentice-Hall.

Wickramasinghe, B. (2015). Sri Lanka-Report on the observance of standards and codes (ROSC). Accounting and Auditing.

Xiao, J., Weetman, P., \& Sun, M. (2004). Political influence and coexistence of a uniform accounting system and accounting standards: Recent development in China. ABACU, 4O(2), 193-218.

Young, D., \& Guenther, D. (2003). Financial reporting environments and international capital mobility. Journal of Accounting Research, 41(3), 553-579.

Zeghal, D., \& Mhedhbi, K. (2006). An analysis of the factors affecting the adoption of international accounting standards by developing countries. The International Journal of Accounting, 41, 373-386.

Zhang, Y., Andrew, J., \& Collier, H. (2007). The convergence of IFRS in China: A view on the influence of political ideology on Chinese accounting profession. Working paper, ACE International Conference, Hong Kong, China. 